\title{
Recent Borrowing from the U.S. Discount Window: Some Cases
}

Huberto M. Ennis, Sara Ho, and Elliot C. Tobin

$\mathrm{F}$ ederal Reserve Banks, through their respective discount window facilities, make loans to depository institutions on a regular basis. The main purpose of the discount window is to serve as a backup source of short-term funding for banks. When a bank finds itself short of reserves on any given day, the discount window can provide that liquidity at short notice, as long as the bank has entered the necessary lending agreements with the corresponding Reserve Bank. In general, discount window loans are provided at a rate that is higher than market rates and, in consequence, are not expected to constitute a regular source of funding for banks.

The discount window can play a critical role during periods of general financial distress. For example, the Federal Reserve used the discount window to grant substantial amounts of credit to financial institutions during the 2008-09 financial crisis (see Berger et al. 2017). This role of the central bank as lender of last resort during crises has been a topic of debate since the times of Henry Thornton and Walter Bagehot (see Humphrey 1989). Much less studied is the role of the discount window during normal times, outside of crises.

The Fed's discount window is open at all times. Two common objectives attributed to the discount window during normal times are (1) increasing interest rate control in a system of monetary policy implementation based on targeting an interbank rate; and (2) emergency

We would like to thank James Geary, Jeff Gerlach, Bob King, Ben Malin, Toan Phan, Luna Shen, John Weinberg, and Alex Wolman for useful comments on a previous draft. The views expressed in this paper are those of the authors and do not necessarily represent the views of the Federal Reserve Bank of Richmond or the Federal Reserve System. 
funding for banks suffering a purely idiosyncratic, adverse liquidity event. The first objective is mostly muted in a period when the banking system is operating with very large quantities of excess reserves, as has been the case in the U.S. since 2009. The second objective is much more difficult to evaluate given the idiosyncratic nature of the phenomenon and the well-known complications associated with distinguishing liquidity from solvency events. The material discussed in this paper is intended to provide a forensic perspective on the issues associated with evaluating the second objective described above.

Since 2010, the Federal Reserve makes public every transaction at the discount window after a two-year delay. This newly available information provides an opportunity to better understand the reasons why banks borrow from the discount window during normal times. Understanding the needs that the discount window fulfills is important to assess the various features in the organization of the facility and, ultimately, whether such a facility is needed in the first place. A highlevel review of the transactions data reveals that there is a lot of variety among discount window loans in the recent past. Taking an individualloan perspective and looking at the specific conditions under which some of those loans happened, then, seems a promising avenue for improving our understanding of the role of the discount window during normal times.

In this article, we review the details of several loan events that occurred between July 2010 and March 2017. We select which loans to review based on some basic criteria: size of the loan, size of the borrower (measured by assets), frequency of lending by the borrower, and other similar characteristics. We further investigate the conditions under which the loan took place, reviewing the financial statements of the borrower around the time of the loan and its pre- and post-loan performance based on publicly available information.

The approach we take in this article is inspired by the idea of "forensic finance" pioneered by Stephen Ross (2002) (see also King [2018] for a recent paper following this approach). Basically, we focus on specific cases of loans at the discount window to try to learn about and better understand the role that this important public program is playing in the financial system. The ultimate objective would be to determine whether the current system serves us well or if there are changes that could be implemented to improve the way public provision of liquidity is handled in financial markets. ${ }^{1}$ We intend to provide evidence

\footnotetext{
${ }^{1}$ For a recent detailed proposal of reform, see, for example, Selgin (2017).
} 
that can aid that evaluation, but we do not intend to provide definitive answers to the broader questions.

Given the limited information available, it is not possible for us to be sure of the reasons that motivated the borrowing in each of the specific cases we study. Instead of speculating on the possible ultimate reasons in each case, our objective is to gain perspective from the combination of all the cases. We summarize this perspective in the following general patterns based on the idea that different banks use the discount window for different reasons and in different ways. Some large healthy banks borrowed from the discount window in amounts that, while large in absolute value, were small relative to the size of the banks. Given the lack of any sign of distress or urgency, the reason for those loans appears to be mainly a matter of convenience: the discount window was readily available and not terribly expensive during that time.

Some banks borrow repeatedly from the discount window for a relatively brief period of time and then stop. In these cases, the discount window appears to have been part of a model for managing liquidity that eventually was discarded - suggesting that the alternatives to using the discount window were not particularly onerous. Finally, using the discount window to lend to banks in poor financial conditions seemed to have exposed the Fed to dealing with institutions that eventually ended up failing and in many cases were later discovered to be associated with fraudulent activities.

The paper is organized as follows. In the next section, we cover some basic facts about discount window policy and the data. In Section 2 , we discuss five important cases concerning primary credit loans. Section 3 looks at four of the most important cases associated with the secondary credit program in our sample period. Finally, Section 4 offers some concluding remarks.

\section{THE FED'S DISCOUNT WINDOW}

There are three programs for making loans via the discount window. The primary credit program is the most widely used and is restricted to well-capitalized institutions. It is mainly a no-questions-asked standing facility that charges a fixed penalty of 50 basis points over the policytarget interest rate.

The secondary credit program is available to those institutions that do not qualify for primary credit. It is associated with a higher level of scrutiny by the Fed, and the interest rate is generally 50 basis points higher than the primary credit rate. 
The seasonal credit program is aimed at satisfying some seasonal demands for liquidity by banks with a particular exposure to such fluctuations. It is fundamentally different from primary and secondary credit in that it is offered for longer terms and not at a penalty rate. A bank borrowing from the seasonal credit program can, in principle, also borrow from another discount window program (primary or secondary, depending on eligibility status) to cover short-term funding needs.

In this paper, we will focus mainly on primary and secondary credit loans, since those are the loans directly associated with the role of the discount window as a backup source of short-term funding for banks. Between July 2010 and March 2017, there were 15,774 primary credit loans and 732 secondary credit loans. Many of these loans are for small amounts and are likely to constitute "test" loans, where the borrowing institution submits a request for a small loan to test the processes involved, with the purpose of ensuring operational readiness. If we take as a threshold that all loans for $\$ 1$ million or lower constitute test loans, then we are left with 3,443 (nontest) primary credit loans and twenty-seven (nontest) secondary credit loans (the last of these secondary credit loans was in February 2015). ${ }^{2}$

Most nontest loans are overnight, but there are some three-day loans that involve weekends, some four-day loans that involve holidays, and some loans of longer maturity, although those are very rare (see Ackon and Ennis 2017, Table 6). In particular, 83 percent of primary credit loans greater than $\$ 1$ million are overnight loans. For secondary credit, that percentage is somewhat lower but still very high (70 percent). Interestingly, many of these overnight loans are rolled over several times. In those cases, it seems more appropriate to consider a sequence of consecutive loans a single "loan event." This is the approach we will take here.

Table 1 shows the number of loans and the total amount lent per year, from 2011 until 2016 (the six complete years in our sample). We also present the total amount lent expressed in overnight equivalents (OEs). This adjustment is intended to make a term loan taken for several days equivalent to several overnight loans taken on those same days. The numbers are not very different because most term loans are relatively small and, overall, there are not that many of them.

Ackon and Ennis (2017) provide a more detailed overview of the general features of the transaction data using the subsample that runs from July 2010 until June 2015. The distribution of loan sizes, the

\footnotetext{
2 There are probably some loans smaller than $\$ 1$ million that are not tests. Still, given their (very) short-term nature, loan amounts smaller than $\$ 1$ million are relatively insignificant, which limits their interest.
} 
Table 1 Discount Window Lending (Loans Greater than \$1 million)

\begin{tabular}{|c|c|c|c|c|c|c|}
\hline \multirow[b]{2}{*}{ Year } & \multicolumn{3}{|c|}{ Primary Credit } & \multicolumn{3}{|c|}{ Secondary Credit } \\
\hline & $\begin{array}{l}\text { No. } \\
\text { of loans }\end{array}$ & $\begin{array}{l}\text { Total amt } \\
\text { lent }(\$ \mathrm{~mm})\end{array}$ & $\begin{array}{l}\text { Total amt lent } \\
(\mathrm{OE})(\$ \mathrm{~mm})\end{array}$ & $\begin{array}{l}\text { No. } \\
\text { of loans }\end{array}$ & $\begin{array}{l}\text { Total amt } \\
\text { lent }(\$ \mathrm{~mm})\end{array}$ & $\begin{array}{l}\text { Total amt lent } \\
(\mathrm{OE})(\$ \mathrm{~mm})\end{array}$ \\
\hline 2011 & 550 & $5,458.12$ & $9,045.04$ & 15 & 48.5 & 69.00 \\
\hline 2012 & 575 & $5,759.42$ & $7,384.47$ & 2 & 6.00 & 6.00 \\
\hline 2013 & 554 & $3,413.82$ & $4,335.69$ & 1 & 3.50 & 3.50 \\
\hline 2014 & 465 & $3,032.71$ & $4,310.22$ & 2 & 3.50 & 3.50 \\
\hline 2015 & 443 & $4,297.92$ & $6,075.72$ & 1 & 1.20 & 4.80 \\
\hline 2016 & 357 & $3,881.34$ & $6,030.91$ & 0 & 0.00 & 0.00 \\
\hline
\end{tabular}

Note: Overnight equivalents (OEs) adjust the data so that term loans lasting for several days are equivalent to a comparable sequence of one-day loans.

term to maturity of loans, the time of the month, quarter, and year when most loans happen, and other features of the data are thoroughly discussed there. Furthermore, Ackon and Ennis (2017) provide an overview of the collateral pledged by borrowing banks and the patterns of utilization of that collateral during the sample period. One lesson that comes through from the inspection of the cross-sectional data is that there is a lot of heterogeneity across these discount window loans and much of the variation does not seem to involve clear common patterns. Idiosyncratic factors, the focus of this paper, seem to matter a lot.

To borrow at the primary credit program, a depository institution needs to be in generally sound financial condition. Reserve Banks review institutions on a regular basis, assessing capital adequacy, asset quality, management, liquidity and other general aspects of bank health. As a result of the supervisory examination, each institution is assigned a rating called the CAMEL rating. A rating of 1 is the strongest qualification, and a rating of 5 is the weakest. To be eligible to borrow at the primary credit program, an institution has to be adequately capitalized, with a CAMEL rating of 1,2 , or 3 (unless supplementary information indicates that the institution is not generally sound). CAMEL ratings are confidential, but to gain some insight on the financial conditions of the banks in our cases, we will often report the capital ratios and how those compare with regulatory requirements at the time.

The provision of credit at the discount window needs to be secured with eligible collateral pledged at the corresponding Reserve Bank. Most performing assets held by institutions are acceptable as discount window collateral but are assigned a lendable value, which often in- 
volves appropriate discounts, or haircuts. The published transaction data include the amount and composition of the collateral pledged by the borrower at the time when the loan happens. We will discuss this information below for the cases (loans) that we study.

\section{PRIMARY CREDIT LOANS}

Primary credit loans are the most common discount window loans. As these loans are granted to depository institutions in good financial condition, several of them are relatively large banks. For the same reasons, some of the primary credit loans tend to be much larger than the ones granted through the other two discount window programs. Here, we will discuss five lending events: the first involves the largest primary credit loan in our sample. After that, we discuss two loans taken by relatively large depository institutions. Finally, we deal with two prominent repeat borrowers (i.e., banks that took a large number of loans in a given period).

\section{The largest primary credit loan in the sample}

Case 1. On November 24, 2010, First Tennessee Bank of Memphis, Tennessee, borrowed $\$ 1.017$ billion from the primary credit program at the St. Louis Fed. The term of the loan was two days, as November 25, 2010, was the Thanksgiving holiday in the U.S. The amount of the loan was equal to 42 percent of the pledge collateral that First Tennessee had at the discount window.

Aside from this large loan, First Tennessee took two other smaller nontest loans at the discount window during our sample period: one in February 2011 for $\$ 20$ million, and one in August 2012 for $\$ 100$ million (see the black dots in Figure 1, with the corresponding scale in the right axis; the shaded area indicates time outside of our sample period, which starts in July 2010 and ends in March 2017). Finally, there is only one more loan from First Tennessee in our data. This is a small loan for $\$ 1$ million in September 2015 - likely to be a "test" loan and hence not a loan we want to focus on.

The collateral available to First Tennessee was plentiful in all cases. In terms of the composition of the pledged collateral, around 60 percent was in the form of commercial loans and 40 percent was in commercial real estate loans, with only a small proportion left to consumer loans in some instances. This is similar for all four transactions in our dataset.

First Tennessee is a regional bank operating mainly in the southeast area of the U.S. It is the main bank subsidiary of First Horizon National Corporation (FHNC), a bank-holding company that in 2010 had over 
Figure 1 First Tennessee Bank

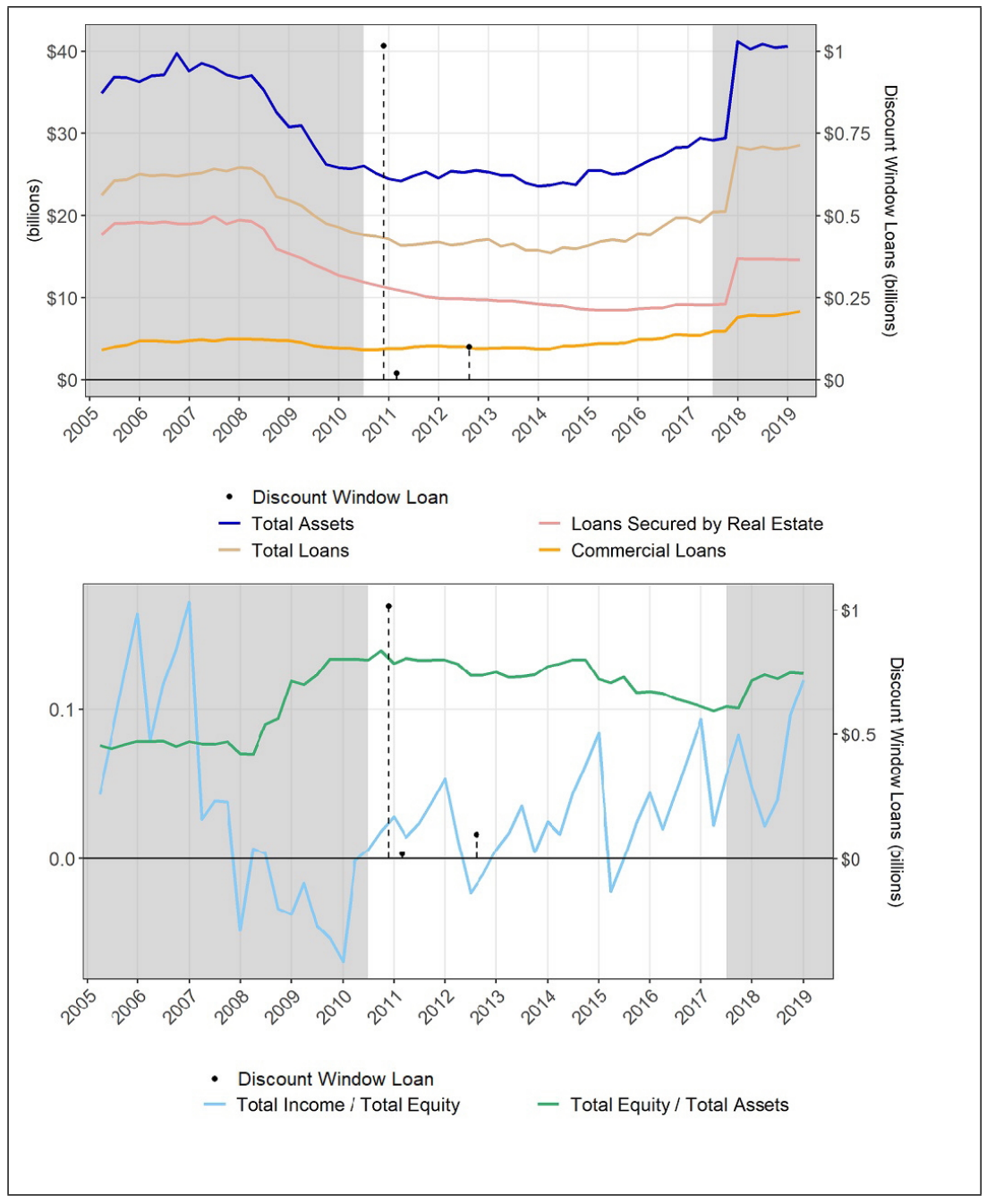

Note: The unshaded area represents the period of time covered by our sample.

$\$ 24$ billion in assets (as of December 2018, the asset-size of FHNC was $\$ 40$ billion). After the financial crisis, First Tennessee moved to refocus its strategic direction away from mortgage banking and toward more traditional lending and deposit-taking services aimed at consumers and businesses. This reorganization was well underway when the bank took the large loan at the discount window in November 2010. 
In Figure 1, we can see that First Tennessee's reaction to the crisis was to become smaller and to refocus. ${ }^{3}$ By mid-to-late 2010, when the large discount window loan happened, First Tennessee had returned to positive profitability, increasing its lending and securities operations. That period in late 2010 was also an important time for First Tennessee because they issued equity and long-term debt and used the proceeds to redeem roughly $\$ 850$ million in TARP money, which they had received during the height of the financial crisis. In the available public information we have reviewed, we were not able to find any specific event that could be directly linked to the large discount window loan of November 2010.

\section{Large-bank borrowing}

Case 2. Barclays Bank of Wilmington, Delaware, borrowed $\$ 50$ million from the primary credit program of the Philadelphia Fed on July 17, 2014. In April of the previous year, Barclays Bank of DE also borrowed $\$ 10$ million from the same program. Both loans were overnight, and in both cases the collateral the bank had pledged at the discount window was orders of magnitude larger than the amount borrowed ( $\$ 6$ billion and $\$ 4.7$ billion, respectively). There are two other loans from Barclays in our dataset, one in August 2015 and one in October 2016, but they are both for $\$ 10,000$ and, in all likelihood, given the small amount, just for the purpose of testing the operational readiness of the systems involved.

Barclays Bank of DE provides consumer and small-business credit programs in the U.S., including credit cards and personal loans. It is part of Barclays Corporation, a U.K.-based global financial firm. Barclays bank in the U.K. also owns a foreign branch in New York that is separate from the Delaware operations. Within our sample, there is actually one loan for $\$ 1$ million taken by the New York branch of the U.K. bank in November 2016.

In 2014, when the loans under consideration happened, the U.S. credit card portfolio of Barclays Bank of DE was quite large, with around $\$ 20$ billion in assets. ${ }^{4}$ In July 2016, the Delaware bank became an operating subsidiary of the newly created international holding company under which Barclays moved to consolidate all its operations in the U.S. At least since then, the bank has been subject to numerous

\footnotetext{
${ }^{3}$ By 2016, the bank had resumed growth and, in November 2017, it completed the acquisition of Capital Bank, a North Carolina bank with $\$ 10$ billion in assets.

4 At the time of writing (December 2018), Barclays Bank of DE was still a large credit card provider in the U.S. with nearly $\$ 35$ billion in assets. The U.S. operation amounts to around 2 percent of Barclays Corporation's total global assets.
} 
regulations aimed at "large" bank holding companies, such as umbrella supervision by the Federal Reserve, stress testing, and the regular submission of resolution plans (living wills).

At the time of the discount window loans in 2014, Barclays, like many other large banking corporations operating in the U.S., was undergoing significant changes in its legal structure in a move to ring-fence some of its critical operations. Still, in its 2014 resolution plan, Barclays reported that they had a centralized management structure to deal with capital and liquidity needs across the global corporation. For a company the size of Barclays Corporation, with over a trillion dollars in global assets, the amounts borrowed at the discount window were, relatively speaking, very small.

Case 3. The New York branch of Banco Bilbao Vizcaya Argentaria (BBVA) took two $\$ 100$ million loans from the New York Fed's primary credit program in October 2010 and then another loan for the same amount in November 2011. Aside from those (more significant) loans, the branch has taken several (much) smaller loans over the years that are likely to constitute test loans. For the three large $\$ 100$ million loans, such amount was over 70 percent of the pledged collateral that the branch had at the discount window, with the lion's share of the collateral (over 92 percent of the total) in the form of international securities.

BBVA is a Spanish multinational banking organization and one of the largest financial institutions in the world. The N.Y. branch of BBVA is a direct subsidiary of the global international bank. Aside from the foreign-bank branch, the BBVA Group also owns a commercial bank operating in the U.S., BBVA Compass, with significant presence in the Sunbelt states. ${ }^{5}$

In other words, the N.Y. branch of BBVA, which took the discount window loans we are discussing, is part of a much larger banking organization with, at the time of the loans, over $\$ 500$ billion in total assets and large cash reserves (around $\$ 20$ billion). These facts suggest that the overnight loans taken by the BBVA N.Y. branch may have been the result of relatively small, urgent (short-term) demands for cash and that the bank considered the discount window the most convenient avenue to fulfill them.

These loans are particularly interesting in view of the fact that around that time the business models of many U.S. branches of foreign banks were shifting toward high participation in the intermediation of

\footnotetext{
${ }^{5}$ The BBVA Group had also a bank subsidiary in Puerto Rico that actually took a $\$ 5$ million overnight loan from the primary credit program at the New York Fed in March 2011.
} 
interest on reserves (Goulding and Nolle 2012). Branches of foreign banks have a comparative advantage, relative to more heavily regulated commercial banks, in the process of taking deposits from private investors and holding them as interest-paying reserves in their accounts at the Federal Reserve. This activity results in branches holding large quantities of reserves (and liquidity), which would tend to make the need for a discount window loan very rare.

\section{Repeat borrowers}

Case 4. From October 2010 until July 2013, ViewPoint Bank of Plano, Texas, borrowed thirty-nine times from the primary credit program at the Dallas Fed. Loan amounts range from $\$ 2$ million to $\$ 35$ million, which is a large sum for a discount window loan but still relatively minor for a midsize bank with around $\$ 4$ billion in assets and $\$ 500$ million in equity capital, as ViewPoint was at the time.

While many of the loans taken by ViewPoint were in consecutive days (about half of them), it is hard in this case to characterized consecutive loans as the same loan event because the loan amounts were generally very different (sometimes larger and sometimes smaller than the preceding day's loan). Many of the loans happened toward the end of the month, but not always. The pattern of borrowing suggests that the bank might have been using the discount window as a regular source of short-term funding.

When ViewPoint took its largest discount window loan (for $\$ 35$ million) in July 2011, all its collateral was in the form of mortgage-backed securities (MBS). This large overnight loan used 93 percent of the total pledged collateral (a relatively high utilization rate) and was fully repaid at maturity (overnight). After that event, ViewPoint increased the amount of collateral pledged at the discount window significantly, but the composition did not change - all MBS. The thirty-seven loans that came after the July 2011 loan were all much smaller, and none of them amounted to more that 25 percent of the collateral available to ViewPoint at the discount window.

ViewPoint started as a credit union and became a bank in 2005 . At the time when the bulk of the discount window loans happened (2011-12), the bank was undergoing significant transformations. The proportion of loans in assets was increasing and the proportion of securities decreasing (see Figure 2). Similarly, loan concentration in real estate started to decrease in 2012 from levels close to 90 percent of total loans in 2011. During the first quarter of 2013, the amount of loans secured by 1-4 family residential properties in ViewPoint's balance sheet fell by over a billion dollars. At the same time, loans to nondepository 


\section{Figure 2 ViewPoint Bank}

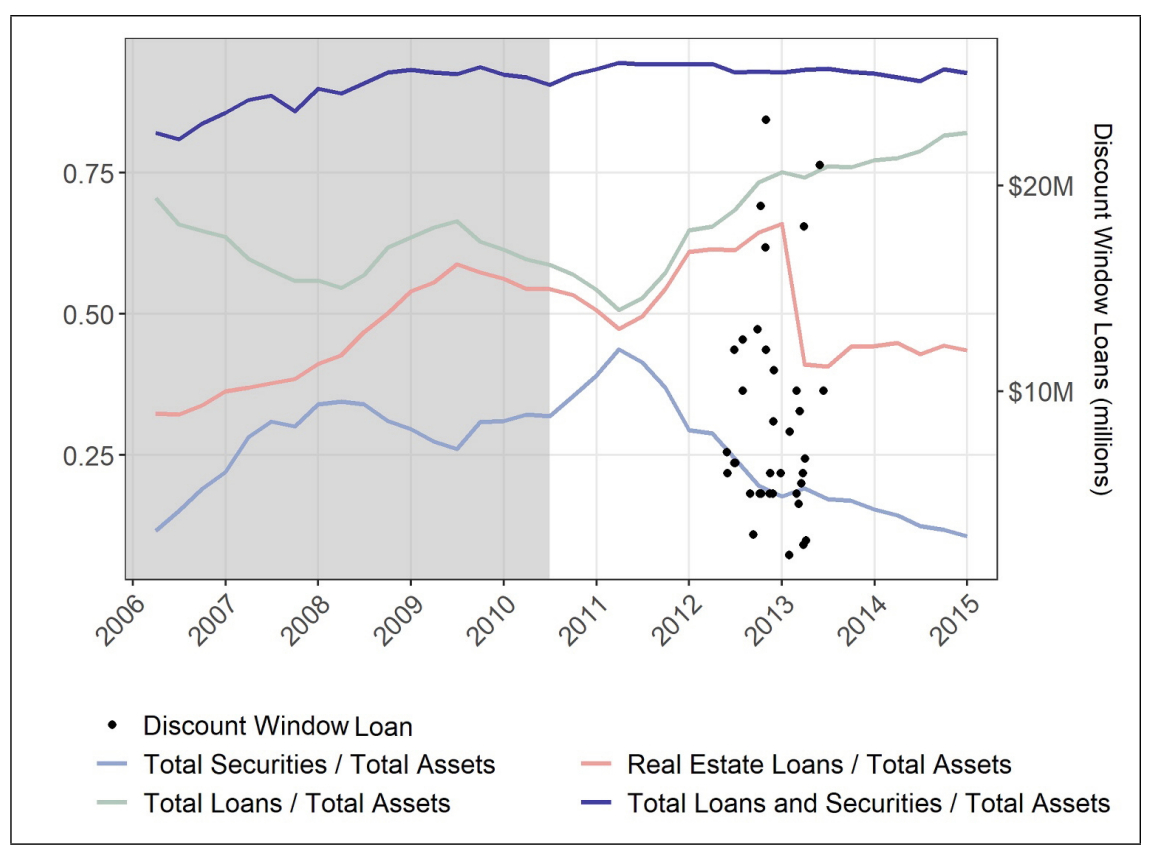

financial institutions increased by $\$ 750$ million. In principle, this move should have reduced ViewPoint's exposure to real estate risk, although possibly not for the whole amount of the change.

Late in 2013, ViewPoint announced plans to merge with LegacyTexas bank and become part of LegacyTexas Financial Group, a publicly traded company. The merger was completed in the first months of 2015. The time of the announcement of the merger is interesting because it was only a few months after ViewPoint took the last discount window loan (as reported in our sample). This suggests, perhaps, that in the process of arranging the merger, a determination was made to no longer use the discount window on a regular basis. ${ }^{6}$

Case 5. Between October 2011 and January 2013, Texas Capital Bank of Dallas, Texas, borrowed thirty-five times from the discount window primary credit program of the Dallas Fed. After January 2013, the bank never borrowed again from the discount window until the end

${ }^{6}$ It could of course be the case that the prospects of a beneficial merger also improved ViewPoint's access to short-term funding, helping the bank to stay away from borrowing at the discount window. 


\section{Figure 3 Texas Capital Bank}

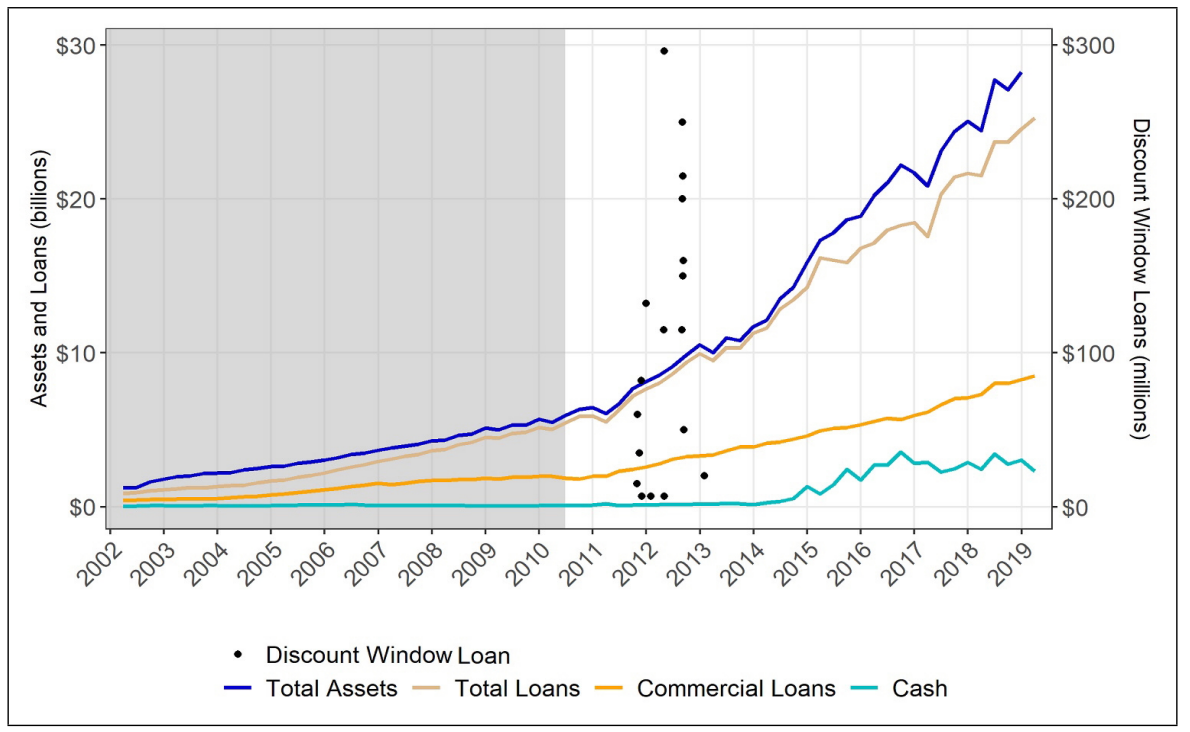

of our sample period. Many of the discount window loans by Texas Capital were significant: ten of the thirty-five loans were for over $\$ 100$ million and four were for $\$ 200$ million or more, with the maximum loan amount being $\$ 296$ million (see the black dots in Figure 3, with the corresponding scale in the right axis). These amounts make it one of the banks that borrowed the most from the discount window during our sample period.

Texas Capital had abundant collateral pledged at the discount window over the period under consideration. In all cases, the discount window loans amounted to less than 20 percent of the pledged collateral, and in most cases this ratio was below 10 percent. All pledged collateral came from their commercial and industrial loans portfolio.

Texas Capital was founded in 1998 with a focus on business lending and has grown consistently since its creation (see Figure 3). In 2003, the bank had its IPO, and, since then, it has been listed in the NASDAQ exchange. Most of the bank's assets are loans and leases, with commercial and industrial loans accounting for over a third of the total. The bank was profitable during the period of our sample and was growing particularly fast in the years when it took the bulk of the discount window loans under consideration. At the same time, the bank had a relatively low cash-to-assets ratio, which suggests that some of the discount window loans might have worked as a backup source of funding 
in the process of expanding its operations. The bank's cash holdings increased considerably after 2013, and it is likely that this change in their balance sheet made borrowing at the discount window much less relevant (see Figure 3).

\section{SECONDARY CREDIT LOANS}

Since secondary credit loans are, in principle, subject to much more scrutiny from the Fed and, during the period under consideration, the number of banks that do not qualify for primary credit is much smaller than the ones that do, there are a lot fewer secondary credit loans in the sample. We concentrate attention in the two most important loan events (by borrowed amount) and the main two repeat borrowers (by number of loans taken). ${ }^{7}$

\section{The largest secondary credit loans in the sample}

Case 6. In the final week of 2010, Nova Bank of Berwyn, Pennsylvania, borrowed two consecutive loans for $\$ 17$ million from the secondary credit program at the Philadelphia Fed's discount window. This was the loan event involving the largest borrowed amount from the secondary credit program during our sample. In October 2012, Nova Bank was liquidated and closed. Later investigations revealed fraudulent behavior by Nova's managers between 2009 and 2010 .

The first loan was taken on Friday, December 24, 2010, for four days at an interest rate of 1.25 percent, which was 100 basis points higher than the target policy rate at the time. On December 28, 2010, Nova renewed the loan for a period of two days, but this time the reported interest rate was 6.25 percent, an unusually high number. On December 30, Nova repaid the loan and never borrowed any significant amount again at the discount window. ${ }^{8}$

\footnotetext{
7 Aside from the four banks involved in our Cases 6 to 9 , there are ten other banks that took loans (thirteen) from the secondary credit program in our sample. Most of those banks are relatively small. Some are still in operation and some have merged or closed.

${ }^{8}$ Within our sample, there is one other discount window loan by Nova for the small amount of $\$ 10,000$, likely to be a test at the secondary credit program during February 2012.
} 
At the time of the borrowing, Nova had $\$ 30$ million in pledged collateral at the discount window, 96 percent of which was in the form of MBS. This is indicative of a more general fact: Nova's focus on real estate lending.

Nova Bank was a relatively small institution that originated from the reorganization of a troubled banking institution in 2002. Even after significant restructuring during the 2000s, of the 60 percent of assets that Nova held in loans at the time of the discount window event, over 40 percent were in commercial real estate (CRE). Compared with the average of 20 to 25 percent for all commercial banks, this can be seen as high concentration in CRE. Furthermore, at the time of the discount window event, 20 percent of Nova's assets were MBS. Adding up these two components showcases Nova's high exposure to real estate risk.

Since its beginnings, Nova never managed to become a profitable enterprise (see Figure 4). Badly hit by the 2008 financial crisis, their regulatory capital position began to deteriorate, and by the time they took the two large discount window loans under consideration, they were clearly undercapitalized. Indeed, in May 2010, the FDIC issued a consent order requiring Nova to meet and maintain an 8 percent minimum tier 1 capital ratio within 180 days from the issuance of the order. Call report data suggest the bank never managed to comply with the order.

The FDIC consent order also included a requirement to develop a plan that would reduce the bank's exposure to CRE. Quarterly balance sheet data suggest that the bank was not very successful in implementing such a plan. If anything, the bank's asset concentration in real estate increased (moderately) after 2010.

At the time of the discount window loans, the bank had only $\$ 14$ million in tier 1 capital, so the amount of the loans ( $\$ 17$ million) was actually larger than the amount of capital at the bank. This suggests that Nova was over-reliant on short-term funding when they accessed the discount window.

Funding issues were not a new development for Nova Bank. In June 2009 (a year and a half before the discount window loans), the bank was approved to receive $\$ 13.5$ million from the Troubled Asset Relief Program (TARP). The TARP funds were contingent on Nova's ability to raise an extra $\$ 15$ million of private capital. It was later discovered that the bank's chairman and the bank's CEO engaged in fraudulent activity in order to obtain the additional private capital. Ultimately, the bank did not receive the money from TARP, and in 2016, both executives were fined and received prison sentences. 
Figure 4 Nova Bank

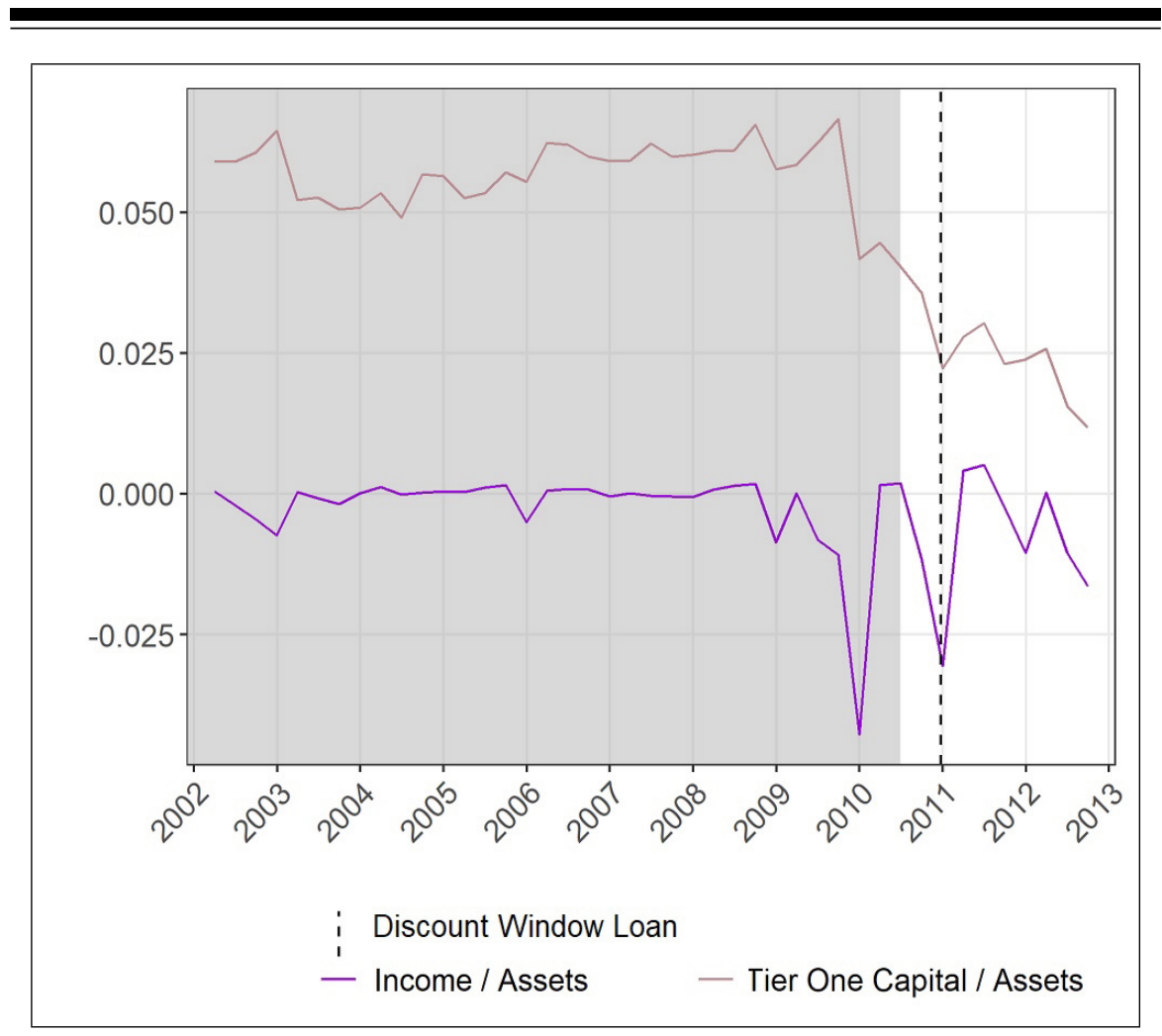

Case 7. In the spring of 2011, Country Bank of Aledo, Illinois, took two consecutive overnight loans for $\$ 9$ million from the secondary credit program at the Chicago Fed's discount window. This was the second largest loan amount for a loan event in our sample of secondary credit transactions. Country Bank had $\$ 10.3$ million in pledged collateral at the time, with 23 percent being commercial loans, 33 percent CRE loans, and 43 percent consumer loans.

Country Bank was a small bank with approximately $\$ 200$ million in assets in 2011. The bank was founded in 2000 and performed relatively well until the financial crisis. The bank had some significant losses in 2010 associated with its MBS portfolio and a significant loss associated with its lending activities in early 2011. Eventually, in October 2011, Country Bank was closed by state regulators for following unsafe and unsound banking practices, with Blackhawk Bank and Trust acquiring $\$ 113$ million of Country Bank's assets and the remaining problem loans 


\section{Figure 5 First Bank of Greenwich and Merchant's Bank discount window loans}

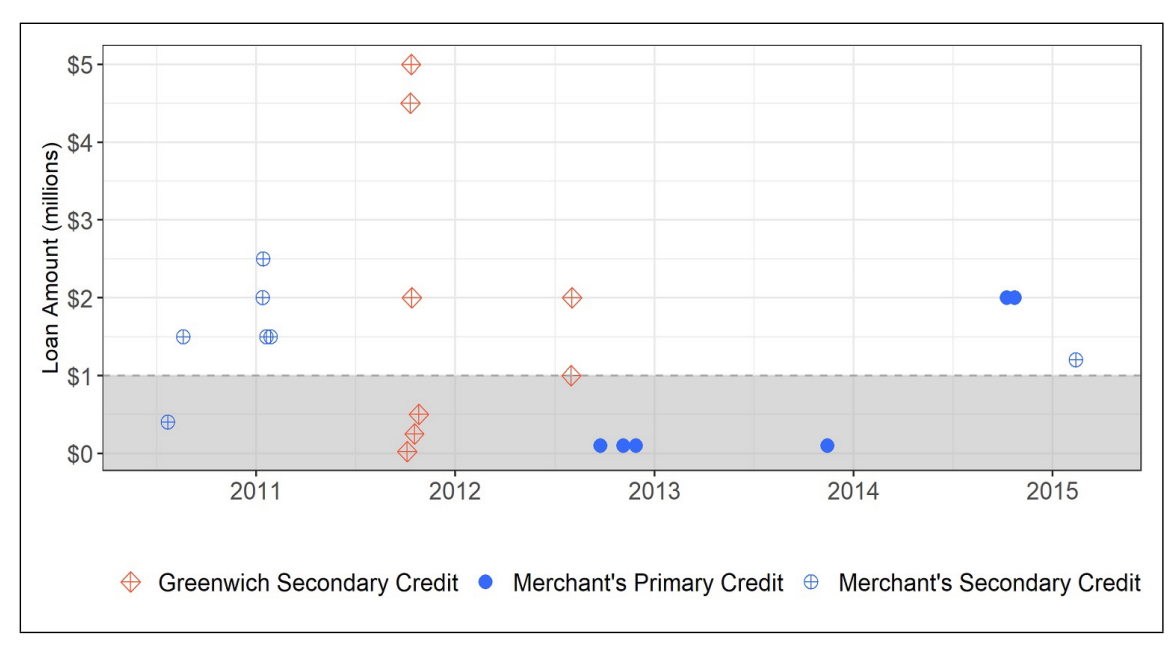

Note: The shaded area indicates loans under $\$ 1$ million, which are likely to be tests.

transferred to the FDIC. At the time of the failure, the FDIC estimated that the cost to the Insurance Fund would be over $\$ 66$ million.

It was later revealed that Country Bank had a significant exposure to a real estate developer who had misrepresented financial statements and eventually defaulted on the loans. The bank filed foreclosure claims for multiple properties associated with that individual developer but was not able to recoup the money. The developer had other loans, including one large loan from the U.S. Department of Agriculture for which he was indicted after providing false information.

\section{Repeat borrowers}

Case 8. First Bank of Greenwich of Cos Cob, Connecticut, borrowed eight times from the secondary credit program of the New York Fed during our sample period, six times in October 2011 and two more times in August 2012. Three of the loans in October 2011 were back-to-back but involved different loan amounts, first higher and then lower than the initially borrowed amount (which suggests a gradual pay down of the loan). All of Greenwich's collateral at the discount window was in the form of Treasury securities. 
As a local community bank with under $\$ 100$ million in assets at the time, the First Bank of Greenwich was hit hard by the financial crisis in 2008-09 and was starting its recovery by the time we find it in our dataset. In fact, in May 2010, the FDIC demanded First Bank of Greenwich submit a management and capital plan that required a significant increase in the bank's capital level. In late 2010 and early 2011, the bank received substantial capital injections from private investors and a new CEO arrived at the bank in April 2011. Since then, the bank has experienced steady asset growth, reaching over $\$ 350$ million in assets by the end of 2018 .

An interesting fact in this case is that the First Bank of Greenwich borrowed from the discount window during a time when it was being closely monitored by regulators - as the management and capital plans were in the early stages of implementation. Many of the discount window loans were relatively large for a small bank the size of First Bank of Greenwich (see Figure 5; the shaded area indicates loans under $\$ 1$ million, which are likely to be tests) but all of them were overnight loans backed by very high-quality collateral (Treasuries). Furthermore, after 2012, the First Bank of Greenwich does not borrow again from the discount window (at least until after the end of our sample period in 2017).

Case 9. Between July 2010 and January 2011, Merchants Bank of California took six discount window loans at the secondary credit program of the San Francisco Fed. Sometime before September 2012, the bank switched to being well-capitalized and hence able to borrow at the primary credit program. For the next two years, the bank borrowed six more times from the primary credit program - although only the last two, which happened in October 2014, were for amounts larger than $\$ 1$ million (in both cases the loans were for $\$ 2$ million). Finally, in February 2015, the bank reappeared at the secondary credit program with a loan of $\$ 1.2$ million, the last loan from this bank in our sample (see Figure 5). This discount window activity by Merchants Bank makes it the second most frequent borrower at the secondary credit program (after First Bank of Greenwich, our Case 8 above) during the sample period. ${ }^{9}$

Merchants' collateral pledged at the discount window was mainly composed of commercial and CRE loans, so the bank was not using the discount window to monetize Treasury securities (as, for example, the First Bank of Greenwich was doing in our Case 8). Instead, the dis-

\footnotetext{
${ }^{9}$ Most loans by Merchants were overnight, although a few were three-day loans over a weekend and two were four-day loans involving a weekend followed by a U.S. holiday.
} 


\section{Figure 6 Merchants Bank}

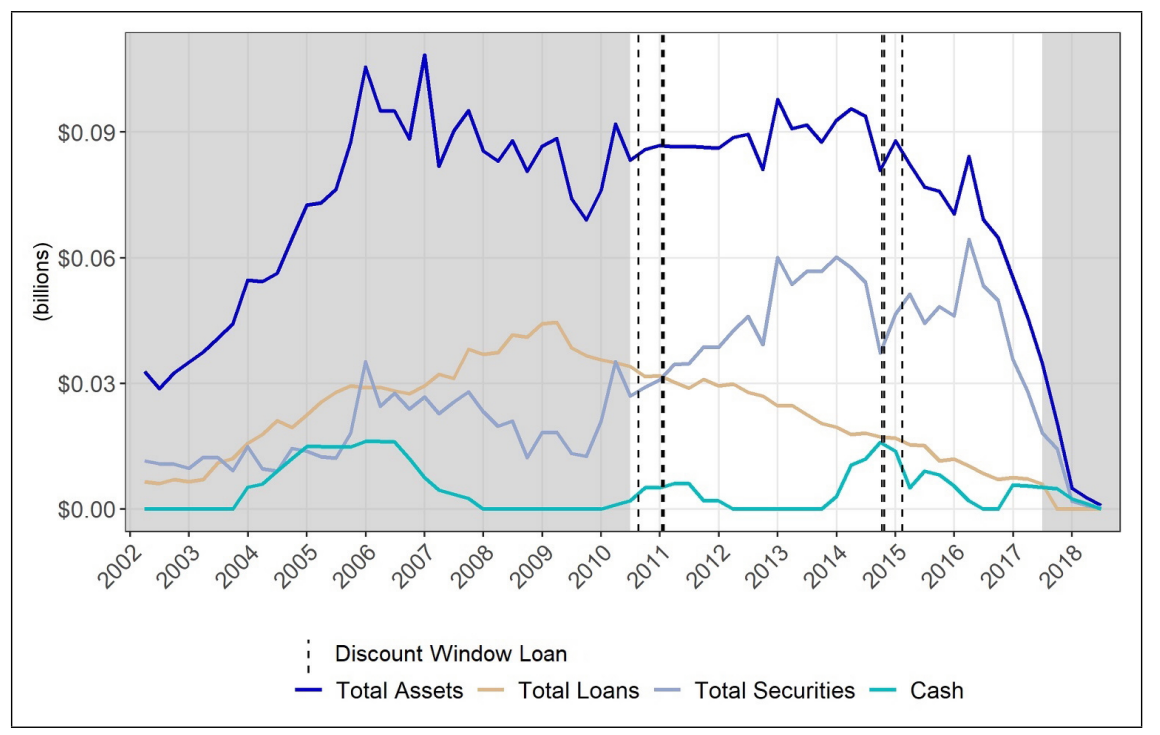

count window was monetizing loans that in all likelihood were relatively illiquid.

Merchants was a small bank (around $\$ 100$ million in total assets) located in Carson, California, that specialized in banking for money services businesses such as check cashers and money transmitters (which provide money transfers and other payment services to their customers). Merchants' main business required the handling and administration of large volumes of cash. For example, Merchants had over 150 check-cashing customers (see FinCEN 2017). Volatile cash flows naturally require a significant buffer of cash, and this is reflected in Merchants' balance sheet (see Figure 6). It is interesting, however, that even with a relatively large proportion of assets in the form of cash and balances (i.e., reserves and deposits in other banks), Merchants still needed to tap the discount window as a backup source of cash. Of course, the data plotted in Figure 6 represent end of the quarter conditions and it is entirely possible that Merchants experienced large fluctuations in its cash account within the quarter, which could have resulted in shortages and the need to tap the discount window.

In 2016, Merchants' financial conditions deteriorated markedly and, eventually, the bank was closed and liquidated in late 2017. In the last years of its life, Merchants was being investigated for unsafe banking practices in the period between 2012 and 2016, which includes the time 
when the bank was able to borrow from the primary credit program. The investigations revealed that Merchants had been in violation of the Bank Secrecy Act for not properly controlling money-laundering risks. For example, Merchants failed to detect and report suspicious activity related to remittances to and from high-risk jurisdictions (such as Honduras, Romania, Mexico, and Somalia). In the end, the investigation resulted in a $\$ 7$ million fine imposed on Merchants by the U.S. Treasury Department. ${ }^{10}$

The investigation also revealed that Merchants had a very low degree of sophistication in monitoring and documenting account behavior and in performing cash-flow analysis to better understand the way its customers were funding their check-cashing operations. These poor practices may also help explain Merchants high exposure to borrowing from the discount window, as the bank seems to have been ill-equipped to predict its short-term liquidity needs.

\section{CONCLUSION}

For a long time, individual transactions at the discount window were kept confidential. It was hard (if not impossible) for policymakers and academics to get a comprehensive view of the role of the discount window. Even Fed officials were not regularly exposed to a full picture but rather mainly just saw what their individual Reserve Banks were experiencing. The periodic publication (with two-year delay) of transactions data, which started in June 2010, is an opportunity to change that state of affairs.

This paper exploits that opportunity in one particular way. We study transactions or sets of transactions that could be considered especially relevant: the largest; the ones involving repeat borrowers; the ones involving relatively large banks. The transactions analyzed in this paper all occurred during a time of relative calm in financial markets.

The reasons why banks borrow from the discount window appear to be highly idiosyncratic and not a matter of "life or death." Large healthy banks sometimes borrowed significant absolute amounts, but those dollar amounts are relatively small compared with the size of the banks' operations. In those cases, the discount window appears to have been just one of the many ways banks could handle a particular short-term funding event. Healthy repeated borrowers seem to use the discount window more as part of a global funding strategy and in

${ }^{10}$ For further details on the investigations and Merchant's activities, see FinCEN (2017). The Somali connection was reported by Reuters in February 2015. 
general only temporarily. In summary, healthy banks seem to access the discount window mostly for convenience.

The borrowing from the discount window by unhealthy banks appears to be one more manifestation of the inappropriateness of their managerial practices. Such banks are often closed down after some time or are reorganized, at which point they stop using the discount window. Many of those banks that were ultimately closed down seem to have exposed the Fed to dealing with clearly (ex post) undesirable counterparties.

To assess the social value of having a discount window open at all times, it is necessary to understand the benefits of having such a facility open during periods of financial calm. This paper is an attempt to provide a better sense of where those benefits might be and their relative size. Our preliminary conclusion is that in the cases we have studied those benefits do not seem particularly large. It seems likely that with no access to a discount window the banks in our "cases" would have found other ways to deal with their specific funding needs without major implications for relevant economic outcomes. 


\section{REFERENCES}

Ackon, Felix P., and Huberto M. Ennis. 2017. "The Fed's Discount Window: An Overview of Recent Data." Federal Reserve Bank of Richmond Economic Quarterly 103 (First-Fourth Quarter): 37-79.

Berger, Allen N., Lamont K. Black, Christa H.S. Bouwman, and Jennifer Dlugosz. 2017. "Bank Loan Supply Responses to Federal Reserve Emergency Liquidity Facilities." Journal of Financial Intermediation 32 (October): 1-15.

Financial Crimes Enforcement Network (FinCEN). 2017. "Assessment of Civil Money Penalty." U.S Department of the Treasury, Number 2017-02.

Goulding, William, and Daniel E. Nolle. 2012. "Foreign Banks in the US: A Primer." Board of Governors of the Federal Reserve System International Finance Discussion Paper 1064 (November).

Humphrey, Thomas M. 1989. "Lender of Last Resort: the Concept in History." Federal Reserve Bank of Richmond Economic Review 75 (March/April): 8-16.

King, Robert G. 2018. "PPSI 2005 WLL1: Inside a Subprime MBS Deal that Michael Burry Bet Against." Manuscript.

Ross, Stephen A. 2002. "Forensic Finance: ENRON and Others." Rivista Di Politica Economica 92 (November): 9-28.

Selgin, George. 2017. "Reforming Last-Resort Lending: the Flexible Open-Market Alternative." In Prosperity Unleashed: Smarter Financial Regulation, edited by Norbert J. Michel. Washington, D.C.: The Heritage Foundation, 201-12. 